\title{
Template-Directed Syntheses of Configurable and Reconfigurable Molecular Switches
}

\author{
Yi Liu, Sourav Saha, Scott A. Vignon, Amar H. Flood, J. Fraser Stoddart* \\ California NanoSystems Institute and Department of Chemistry and Biochemistry, University of California, Los Angeles, 405 Hilgard \\ Avenue, Los Angeles, CA 90095-1569, USA \\ Fax+1(310)2061843; E-mail: stoddart@chem.ucla.edu \\ Received 15 September 2005 \\ This article is dedicated to Steven Ley on the occasion of his $60^{\text {th }}$ birthday.
}

\begin{abstract}
Two self-complexing compounds based on donor-acceptor interactions, one comprised of a $\pi$-electron-deficient cyclobis(paraquat- $p$-phenylene) $\left(\mathrm{CBPQT}^{4+}\right)$ ring attached to a side-arm component containing $\pi$-electron-rich tetrathiafulvalene (TTF) and 1,5-dioxynaphthalene (DNP) units, and the other comprised of a $\mathrm{CBPQT}^{4+}$ ring carrying two side-arms, one containing a TTF unit and the other a DNP unit have been synthesized. ${ }^{1} \mathrm{H}$ NMR spectroscopy and UV/Vis spectroelectrochemistry have revealed that, while the latter compound behaves as a reconfigurable redox-active molecular switch involving only the side-arm containing the TTF unit in a self-complexing role with the $\mathrm{CBPQT}^{4+}$ ring (the side-arm containing the DNP unit is essentially a 'spectator'), the former compound behaves as a molecular switch that is reversible and reconfigurable when its starting self-complexing conformation is retained, but becomes only configurable and irreversible when the self-complexing conformation is partially transformed into 'uncomplexed' conformation on oxidation of the TTF unit.
\end{abstract}

Key words: molecular recognition, redox reactions, self-assembly, spectroelectrochemistry, templation

Mechanically interlocked molecules - for example, catenanes $^{1}$ and rotxanes ${ }^{2}$ - have already established their credentials as functional molecular machines ${ }^{3,4}$ by virtue of the relative mechanical motions undergone by one component relative to the other component(s) in response to external stimuli in the form of chemical, ${ }^{5}$ electrochemical $^{6}{ }^{\text {and photochemical }}{ }^{7}$ inputs. Another class of mechanically interlocked molecules - the self-complexing donor-acceptor macrocycles ${ }^{8}$ - have their donor units attached covalently to an acceptor ring and is also dependent on molecular recognition between the donor and acceptor units for their unique ability to self-complex and switch mechanically. In the donor-acceptor self-complexing compounds $\mathbf{1} \cdot 4 \mathrm{PF}_{6}$ and $\mathbf{2} \cdot 4 \mathrm{PF}_{6}$ (Figure 1 ), the $\mathrm{CBPQT}^{4+}$ ring is attached covalently to either one or two flexible $\operatorname{arm}(\mathrm{s})$ which contain(s) $\pi$-donating units - namely, TTF and DNP. In both compounds, the ground-state co-conformations (GSCCs) comprise the stronger $\pi$-electron-donating TTF unit encircled by the $\mathrm{CBPQT}^{4+}$ ring. The two-armed, self-complexing compound $1 \cdot 4 \mathrm{PF}_{6}$ has one of its two arms bearing a TTF unit, and the other, a DNP unit. On the other hand, the stoppered, one-armed,

SYNTHESIS 2005, No. 19, pp 3437-3445

Advanced online publication: 14.11.2005

DOI: 10.1055/s-2005-918468; Art ID: C07705SS

(C) Georg Thieme Verlag Stuttgart · New York self-complexing compound $\mathbf{2} \cdot 4 \mathrm{PF}_{6}$ has only one arm which contains both a TTF and a DNP unit. Oxidation and reduction of the TTF unit with an electrochemical stimulus switches the favorable donor-acceptor charge transfer (CT) interactions. Changes in the electronic properties of the molecules then trigger mechanical movements in both systems - an in-and-out motion ${ }^{8}$ of the TTF arm from the CBPQT $4^{+}$ring's cavity in the case of the two-armed, selfcomplexing compound $\mathbf{1} \cdot 4 \mathrm{PF}_{6}$, and a piston-like push-pull movement in the case of the one-armed, self-complexing compound $2 \cdot 4 \mathrm{PF}_{6}$. The redox-induced mechanical behaviors of both these systems have been investigated by NMR spectroscopy, electrochemistry, and spectroelectrochemistry and will be discussed in this paper along with a description of the synthesis of $1 \cdot 4 \mathrm{PF}_{6}$ and $2 \cdot 4 \mathrm{PF}_{6}$.

The synthesis of the two-armed, self-complexing, compound $1.4 \mathrm{PF}_{6}$ is summarized in Scheme 1. Tosylation of the alcohol $3^{9}$ gave the monotosylate 4 , which was reacted
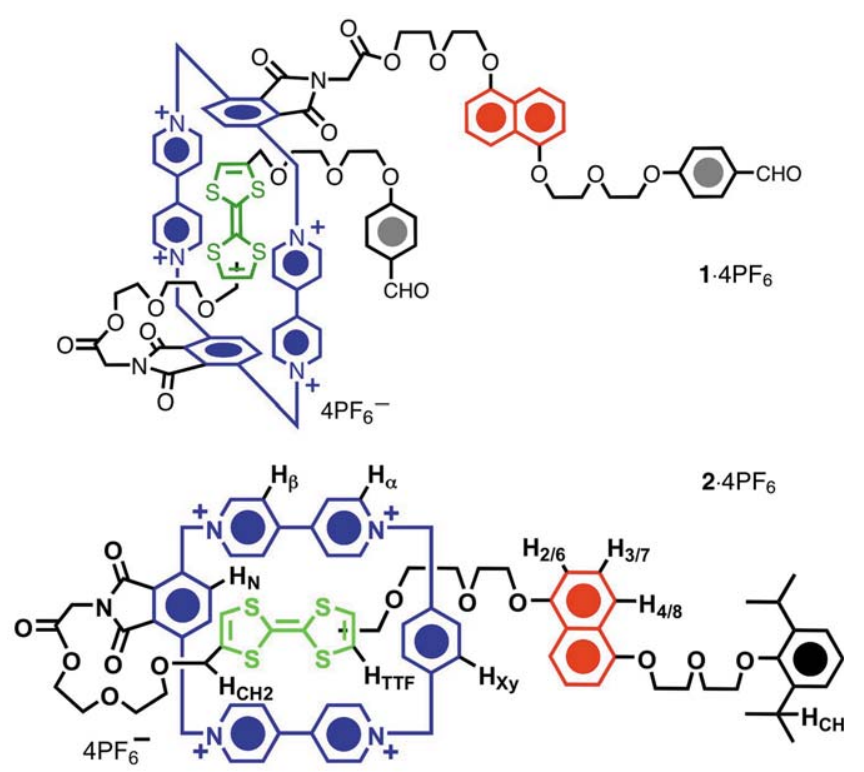

Figure 1 Structural formulas of the two-armed self-complexing compound $1 \cdot 4 \mathrm{PF}_{6}$ and the one-armed self-complexing compound 2. $4 \mathrm{PF}_{6}$. 
with 4-hydroxybenzylaldehyde in the presence of $\mathrm{K}_{2} \mathrm{CO}_{3}$ to produce the alcohol $\mathbf{5}$ in $94 \%$ yield. Esterification of $\mathbf{5}$ with the carboxylic acid derivative $6{ }^{8 \mathrm{~b}}$ using 1,3-dicyclohexylcarbodiimide (DCC) as the coupling agent, gave the dibromide 7 in $76 \%$ yield. Heating of a $\mathrm{MeCN}$ solution of 7 and 4,4'-bipyridine under reflux generated the bis(hexafluorophosphate) salt $\mathbf{8} \cdot 2 \mathrm{PF}_{6}$ after counterion exchange. The final product $1 \cdot 4 \mathrm{PF}_{6}$ was isolated in a yield of $19 \%$ by reaction of $8 \cdot 2 \mathrm{PF}_{6}$ with the TTF-containing dibromide $9,{ }^{8 b}$ followed by counterion exchange and column chromatography.
The synthesis of the stoppered one-armed, self-complexing compound $\mathbf{2} \cdot 4 \mathrm{PF}_{6}$ is summarized in Scheme 2. The alcohol 12 was obtained by reaction of the tosylate $\mathbf{1 1}^{8 \mathrm{~b}}$ with the naphthol derivative $\mathbf{1 0}^{2 e, f}$ in the presence of $\mathrm{K}_{2} \mathrm{CO}_{3}$. Esterification of $\mathbf{1 2}$ with the carboxylic acid derivative $\mathbf{6}^{8 \mathrm{~b}}$ using DCC as the coupling agent, gave the dibromide 13. The final product $2 \cdot 4 \mathrm{PF}_{6}$ was isolated after reaction of the dibromide 13 with the bis(hexafluorophosphate) salt 14.2PF ${ }_{6},{ }^{10}$ followed by counterion exchange and column chromatography.
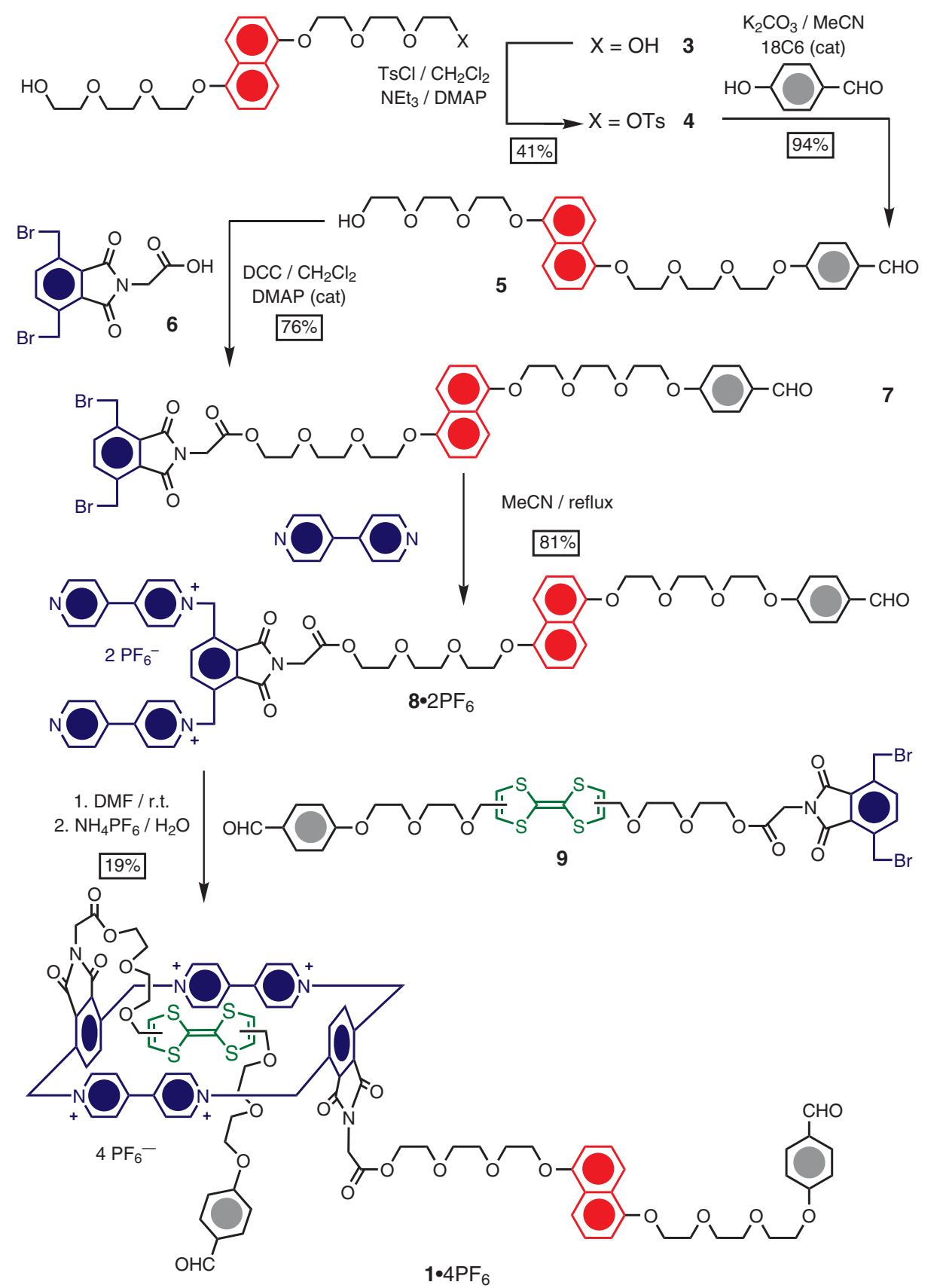

Scheme 1 The synthesis of the two-armed, self-complexing compound 1.4PF 6 . 
The chemically-induced switching of $2 \cdot 4 \mathrm{PF}_{6}$ has been investigated by ${ }^{1} \mathrm{H}$ NMR spectroscopy. The initial spectrum (Figure 2a), which was recorded in acetone- $d_{6}$ at $273 \mathrm{~K}$, revealed an extensive array of overlapping signals that were far from straightforward to assign because of the complex nature of the spectrum. Reasons for this complexity include the presence of multiple isomers arising from two sources. The first one is the cis/trans isomerization of the TTF unit. Secondly, the glycol chain, attached to the unit encircled by the CBPQT ${ }^{4+}$ ring can be either endo or exo. ${ }^{8 \mathrm{~b}}$ This uncertainty leads to the possibility of four different isomers when the TTF unit is encircled by the $\mathrm{CBPQT}^{4+}$. In search of reducing this complexity and forcing the equilibrium to favor solely encirclement of the DNP unit, an oxidation of $2 \cdot 4 \mathrm{PF}_{6}$ was carried out.

The oxidant, tris( $p$-bromophenyl)amminium hexafluoroantimonate, was added (2.0-2.5 equiv) to an acetone- $d_{6}$ solution of $2 \cdot 4 \mathrm{PF}_{6}$, and the ${ }^{1} \mathrm{H}$ NMR spectrum (Figure $2 \mathrm{~b}$ ) was recorded. The number of signals present in the spectrum of the oxidized species (Figure 2b) was considerably reduced relative to those in the starting spectrum (Figure 2a). As a result, it was possible to assign all the signals. Characteristic signals were observed at 9.86 and $9.94 \mathrm{ppm}$ and can be assigned to the TTF protons $\left(\mathrm{H}_{\mathrm{TTF}}\right)$ of the dication. Furthermore, evidence for encirclement of the DNP unit by the CBPQT ${ }^{4+}$ ring was found in the form of signals at 2.80, 2.84, 5.95, 6.34, 6.51 and $6.56 \mathrm{ppm}$,

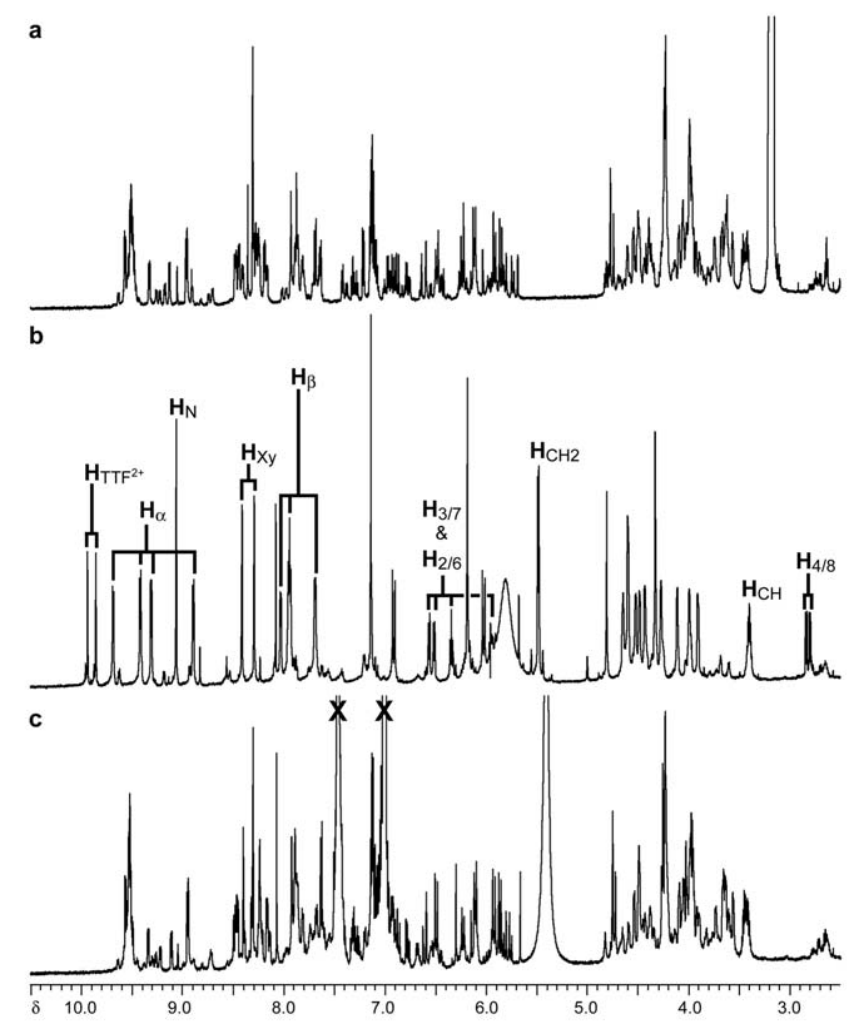

Figure 2 The $600 \mathrm{MHz}{ }^{1} \mathrm{H}$ NMR spectra of $2 \cdot 4 \mathrm{PF}_{6}$ in acetone- $d_{6}$ at $273 \mathrm{~K}$ (a) before addition of oxidant, (b) after addition of 2.0-2.5 equivalents of the oxidant, tris( $p$-bromophenyl)amminium hexafluoroantimonate, and (c) after subsequent reduction using Zinc dust. See Figure 1 for proton assignments. corresponding to two signals each for $\mathrm{H}-4 / 8, \mathrm{H}-3 / 7$ and $\mathrm{H}-$ $2 / 6$, respectively. The large upfield shift of the $\mathrm{H}-4 / 8$ protons, in particular, is characteristic for complexation of the DNP unit. Although it was not possible to determine the identity of the species responsible for the small peaks observed (Figure $2 b$ ) in the spectrum of the oxidized compound, one possibility is the presence of a small amount of dethreaded $2 \cdot 4 \mathrm{PF}_{6}$.

A further experiment was performed to investigate the reversibility of the switching process. A small amount of $\mathrm{Zn}$-dust was added to the oxidized solution of $2 \cdot 4 \mathrm{PF}_{6}$ in order to reduce the species back to its starting state. The ${ }^{1} \mathrm{H}$ NMR spectrum was recorded (Figure 2c) once again. Aside from the appearance of two large signals, corresponding to the reduced form of the oxidant, the spectrum is qualitatively similar to the one observed (Figure $2 \mathrm{a}$ ) before oxidation. This observation suggests that switching has been reversed; however, we cannot confirm or rule out the possibility that the relative ratios of the isomers present have changed as a result of the switching cycle. The relative complexity of the ${ }^{1} \mathrm{H}$ NMR spectra, employed for investigating the redox-driven chemical switching process, provided us with the impetus to investigate its electrochemically controlled mechanical switching.

Electrochemical input is one of the most powerful and 'waste-free' stimuli that can induce mechanical motion in mechanically interlocked molecules. The mechanical motion within such molecules in response to electrons can be monitored by cyclic voltammetry $(\mathrm{CV})$ and/or spectroelectrochemistry, in which UV-Vis absorption spectroscopy is coupled with electrochemistry.

Electrochemically induced mechanical motion in the donor-acceptor compound $1.4 \mathrm{PF}_{6}$ which contains two arms - each bearing one donor unit, either TTF or DNP - was investigated by both $\mathrm{CV}$ and spectroelectrochemistry. The $\mathrm{CV}$ of $1.4 \mathrm{PF}_{6}$ at a scan rate of $200 \mathrm{mV} \mathrm{s}^{-1}$ shows (Figure 3) anodic peaks at $+390,+720$, and $+1280 \mathrm{mV}-$ the first two peaks corresponding to TTF oxidations to the $\mathrm{TTF}^{+}$radical cation and $\mathrm{TTF}^{2+}$ dication respectively, while the third one being associated with the oxidation of the DNP unit. Oxidation of $1 \cdot 4 \mathrm{PF}_{6}$ was found to be fully reversible over 20 cycles with negligible memory effect at various scan-rates. The fact that the DNP unit is oxidized at $+1280 \mathrm{mV}-$ an oxidation potential that is characteristic of the uncomplexed DNP unit - clearly suggests that the DNP-arm does not thread into the cavity of the CBPQT ${ }^{4+}$ ring even after dethreading of the TTF-arm induced by TTF oxidations. This situation can be attributed to a steric hindrance of the $\mathrm{CBPQT}^{4+}$ cavity by the phthalimide adjacent to the TTF-arm. The relative intensity of the $\mathrm{TTF}^{+}$ anodic peak and its precise location in the scan-rate dependent CV studies suggest ${ }^{8 \mathrm{~b}}$ that the TTF unit is in dynamic equilibrium between threaded and dethreaded forms following its oxidation-reduction cycle. At a slower scan rate $\left(5\right.$ and $\left.10 \mathrm{mV} \mathrm{s}^{-1}\right)$, the first oxidation peak splits into two features at +450 and $+520 \mathrm{mV}$. It is not unreasonable to suggest that the $+450 \mathrm{mV}$ peak corresponds to the 


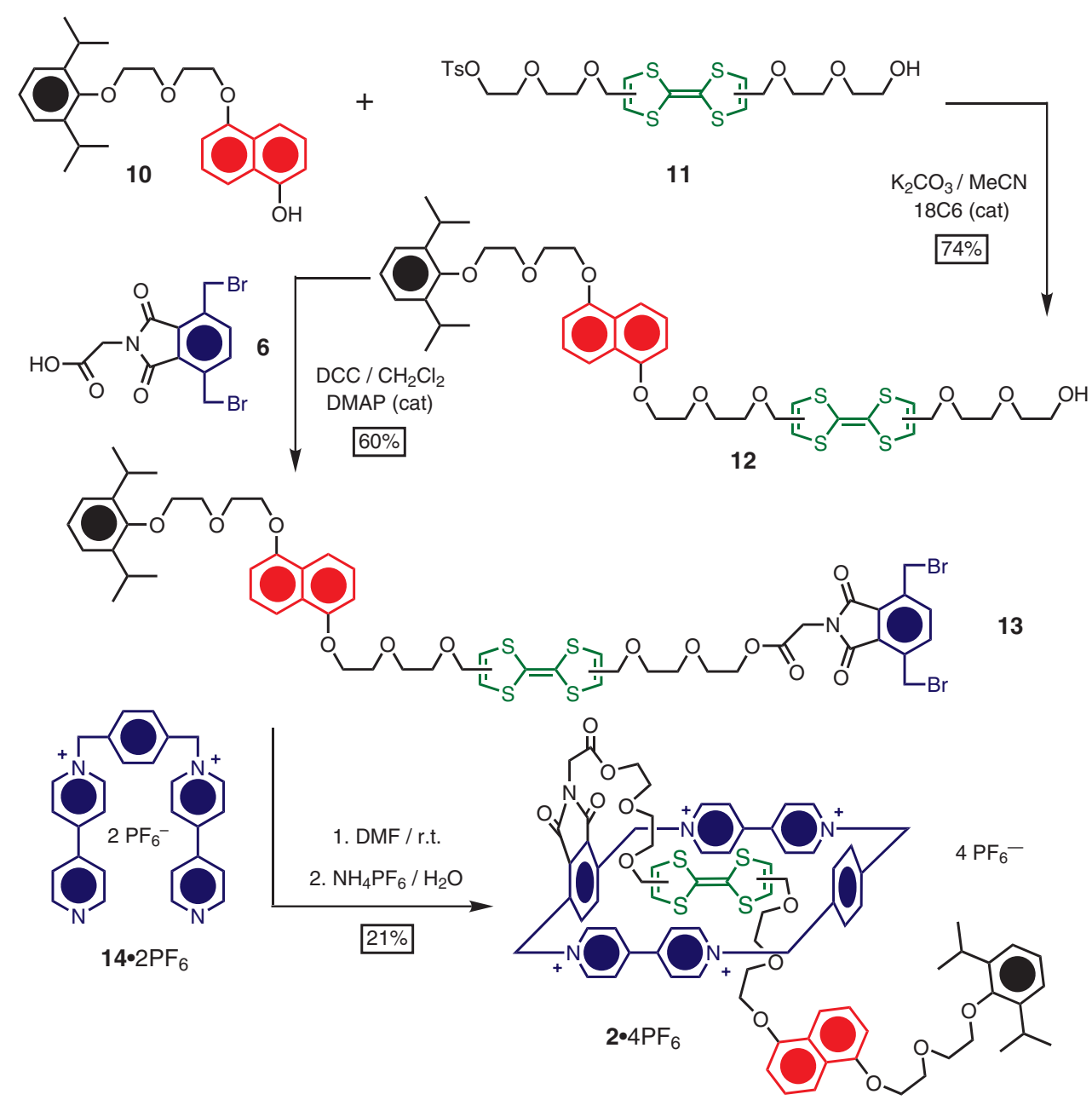

Scheme 2 The synthesis of the stoppered, one-armed, self-complexing compound $2 \cdot 4 \mathrm{PF}_{6}$.

first oxidation of the uncomplexed TTF and the $+520 \mathrm{mV}$ peak arises from the oxidation of the complexed TTF unit.

The reduction of $1.4 \mathrm{PF}_{6}$ at $200 \mathrm{mV} \mathrm{s}^{-1}$ shows a split peak at -260 and $-330 \mathrm{mV}-\mathrm{a}$ feature which is characteristic of the first reduction of a $\mathrm{CBPQT}^{4+}$ ring to the $\mathrm{CBPQT}^{2 / 2+}$

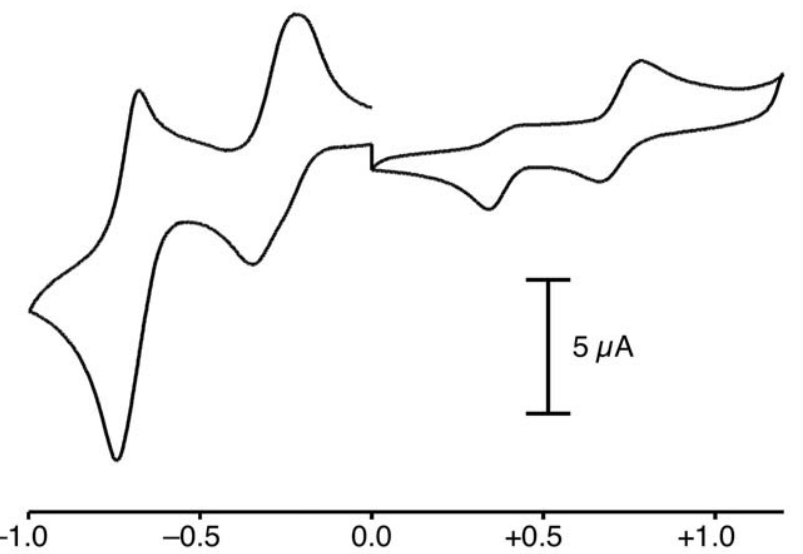

Figure 3 Cyclic voltammetry of $1.4 \mathrm{PF}_{6}(0.1 \mathrm{mM}$ solution in $0.1 \mathrm{M}$ $\mathrm{TBAPF}_{6}-\mathrm{MeCN}$ ) vs. standard calomel electrode (SCE) at a scan-rate of $200 \mathrm{mV} / \mathrm{s}$. diradical form when it encircles a TTF unit in a rotaxane. A second cathodic peak at $-715 \mathrm{mV}$ corresponds to the reduction of the ring component to the neutral $\mathrm{CBPQT}^{0}$ form. The first reduction is fully reversible, whereas the second reduction leads to a small degradation of the subsequent anodic oxidation peaks - a phenomenon which can be attributed to electrode adsorption.

Spectroscopic studies, coupled with electrochemical inputs, also shed light on the switching behavior of $1.4 \mathrm{PF}_{6}$. The GSCC showed (Figure 4, green line) a characteristic band centered on $840 \mathrm{~nm}$ on account of the TTF $\rightarrow$ $\mathrm{CBPQT}^{4+} \mathrm{CT}$ interaction confirming the encapsulation of the TTF-arm into the $\mathrm{CBPQT}^{4+}$ cavity. Oxidation of the TTF unit at an applied potential $\left(E_{\mathrm{ap}}\right)$ of $+750 \mathrm{mV}$ resulted (Figure 4, blue line) in the appearance of $\mathrm{TTF}^{+}$radical cation's absorption peaks at 450 and $600 \mathrm{~nm}$, concomitant with the disappearance of the $840 \mathrm{~nm}$ CT band. These features confirm yet again that once the TTF unit is oxidized, the TTF-arm dethreads from the $\mathrm{CBPQT}^{4+}$ cavity. The second oxidation of the TTF unit to the $\mathrm{TTF}^{2+}$ dication generated (Figure 4, red line) its characteristic peak at 375 nm. However, no DNP $\rightarrow \mathrm{CBPQT}^{4+} \mathrm{CT}$ band at $520 \mathrm{~nm}$ appeared even after prolonged waiting at $E_{\text {ap }}=+1100$ $\mathrm{mV}$, suggesting that the DNP-arm does not complex with 
the $\mathrm{CBPQT}^{4+}$ ring in $1 \cdot 4 \mathrm{PF}_{6}$. Reduction of the $\mathrm{TTF}^{2+}$ dication back to its neutral TTF form regenerated (Figure 4, black line) the $840 \mathrm{~nm}$ CT band, attaining almost its original intensity, indicating the rethreading of the TTF-arm into the $\mathrm{CBPQT}^{4+}$ cavity. A weak peak just below $500 \mathrm{~nm}$ in the final spectrum may be associated with a degradation product or a fraction of still uncomplexed TTF unit. In summary, the TTF-arm of the two-armed, self-complexing, compound $1.4 \mathrm{PF}_{6}$ can be switched in and out of the $\mathrm{CBPQT}^{4+}$ ring by simply stimulating the TTF unit, however, the DNP-arm always remain uncomplexed irrespective of the TTF oxidation states.

Electrochemically induced mechanical movement in the one-armed, self-complexing, compound $\mathbf{2} \cdot 4 \mathrm{PF}_{6}$ was best monitored by spectroelectrochemistry of its $2 \mathrm{mM}$ solution in $\mathrm{MeCN}_{\text {with }} \mathrm{TBAPF}_{6}(0.1 \mathrm{M})$ as the supporting electrolyte. In the ground state of $2 \cdot 4 \mathrm{PF}_{6}$, the side-arm containing the two $\pi$-electron donating units - namely, TTF and DNP - is folded in such a way that the stronger electron-donating TTF unit is encircled by the electronaccepting $\mathrm{CBPQT}^{4+}$ ring - a conformation that displays (Figure 5, green line) a prominent charge-transfer (CT) band centered on $840 \mathrm{~nm}$, corresponding to a CT interaction between a TTF unit and a $\mathrm{CBPQT}^{4+}$ ring. Upon one electron oxidation of the TTF unit to the $\mathrm{TTF}^{+}$radical cation at an applied potential of $+800 \mathrm{mV}$, one observes
(Figure 5, blue line) the characteristic absorption peaks of the radical cation at 450 and $600 \mathrm{~nm}$, concomitant with the disappearance of the $840 \mathrm{~nm}$ band - an observation which suggests that the $\mathrm{CBPQT}^{4+}$ ring moves away from the oxidized $\mathrm{TTF}^{+}$unit. Further oxidation of the TTF unit to its $\mathrm{TTF}^{2+}$ dication at $E_{\text {ap }}=+1100 \mathrm{mV}$ shows (Figure 5, red line) its absorption peak at $375 \mathrm{~nm}$, and a concomitant decay of the $\mathrm{TTF}^{+}$radical cation's absorption peaks reveals a weak, but characteristic, CT band centered on $520 \mathrm{~nm}$ which corresponds to the DNP $\rightarrow \mathrm{CBPQT}^{4+} \mathrm{CT}$ interaction, confirming the ring's relocation around the secondary electron-donating DNP unit. Complete reduction of the $\mathrm{TTF}^{2+}$ dication back to its neutral TTF form at $E_{\text {ap }}=0$ $\mathrm{V}$ should regenerate the original spectrum, provided the mechanical switching process has been completely reversible. After a prolonged reduction $(12 \mathrm{~h})$, however, the spectrum displayed (Figure 5, black line) a modest loss of ca. $40 \%$ in the intensity of the $840 \mathrm{~nm}$ band, implying that fact that not all of the regenerated neutral TTF is encircled by the $\mathrm{CBPQT}^{4+}$ ring. A new, weak band appears at around $500 \mathrm{~nm}$ suggests that some of the $\mathrm{CBPQT}^{4+}$ ring still encircles the DNP station rendering a higher stability of its metastable state. In addition, a complete dethreading of the side-arm component from the cavity of the $\mathrm{CBPQT}^{4+}$ ring by a circumrotation of the phthalimide unit through the ring cannot be ruled out - a process which
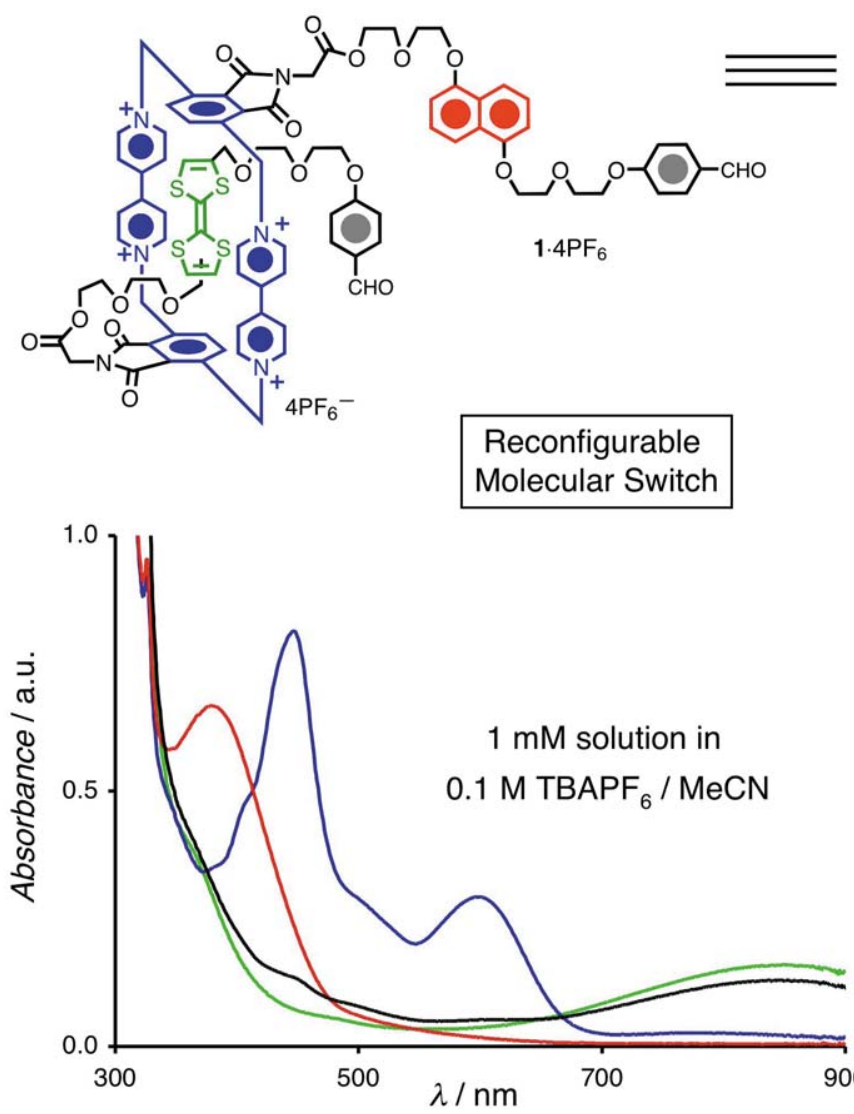

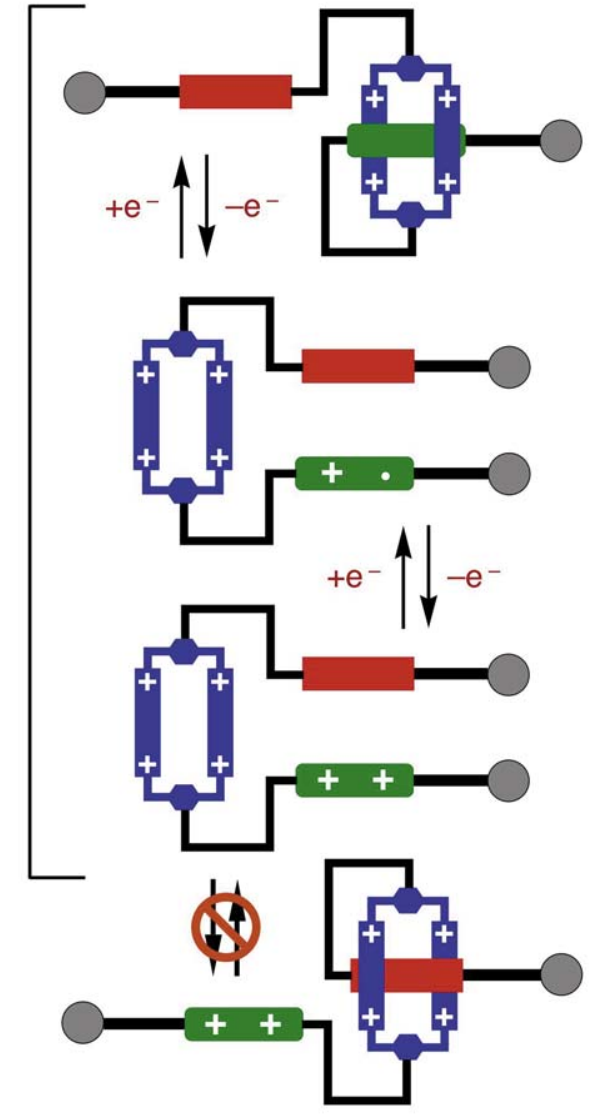

Figure 4 Spectroelectrochemistry and schematic representation illustrating in-and-out motion of the TTF-arm in 1.4PF 6 in response to electrochemical inputs. This motion constitutes a reconfigurable molecular switch. See the text for an explanation of the color-coded spectra. 
does not require that the ring component slips over of the bulky 2,6-diisopropyl aryl stopper at the DNP end in a high-energy process. Once the self-complexing compound is dethreaded into the decomplexed ring plus sidearm components, its rethreading process under diffusion control will be an extremely slow process, if possible at all.

The donor-acceptor rings with one or two arms containing electron-donating recognition sites are a unique class of molecules that have the potential for self-complexation. The integrity of these molecules is not solely dependent on the supramolecular chemistry and molecular recognition as the electron-rich arms are covalently attached to the electron-deficient ring. Nevertheless, their unique self-complexing ability is based on noncovalent interactions between the donor-acceptor units. Furthermore, their redox-stimuli induced mechanical motions stem from noncovalent interactions between the recognition units, which, in turn, allow the arm components to switch within or in and out of the ring's cavity. In the case of the compound carrying one side-arm that contains two recognition units, the redox chemistry behaves in accordance with its being a partially reconfigurable molecular switch, reflecting the fact that one mode of switching leads to a product which does not equilibrate back to its starting conformation. This observation suggests that one mode of switching is irreversible, possibly because the tetrathiafulvalene unit in the 'uncomplexed' conformation is perhaps interacting in an external way with the $\pi$-electron-deficient bipyridinium units of the tetracationic cyclophane. In the case of the compound carrying two side-arms, the redox chemistry behaves in accordance with its being a reconfigurable molecular switch in which only one of the side arms - the one containing the tetrathiafulvalene unit - participates in mechanical switching.

The diol $3,{ }^{9}$ the carboxylic acid derivative $6,{ }^{8 \mathrm{~b}}$ the dibromide $9,{ }^{8 \mathrm{~b}}$ the naphthol derivative $\mathbf{1 0},{ }^{2 \mathrm{e}, \mathrm{f}}$ the monotosylate $\mathbf{1 1},{ }^{\mathrm{b}}$ and the dicationic salt $14 \cdot 2 \mathrm{PF}_{6}{ }^{10}$ were all prepared as reported in the literature. Solvents were purified ${ }^{11}$ according to literature procedures. TLC was carried out using aluminum sheets, precoated with silica gel 60F (Merck 5554). The plates were inspected by UV-light prior to development with iodine vapor. Melting points were determined on an Electrothermal 9200 apparatus and are uncorrected. ${ }^{1} \mathrm{H}$ NMR and ${ }^{13} \mathrm{C}$ NMR spectra were recorded on Bruker Avance 500, Avance 600 or ARX 500 spectrometers using the deuterated solvents as locks and the residual protiated solvents as internal standards. Highresolution electrospray ionization mass spectra (HR-ESI-MS) were obtained using an IonSpec Ultima 7.0T FT-ICR ESI mass spectrometer. High-resolution matrix-assisted-laser-desorption-ionization mass spectra (HR-MALDI-MS) were recorded on an IonSpec Ultima 7.0T FT-ICR MALDI mass spectrometer. The UV-Vis absorption spectra were recorded on a Varian Cary 100 Bio in $\mathrm{MeCN}$ solution. The extinction coefficients were obtained from a single-
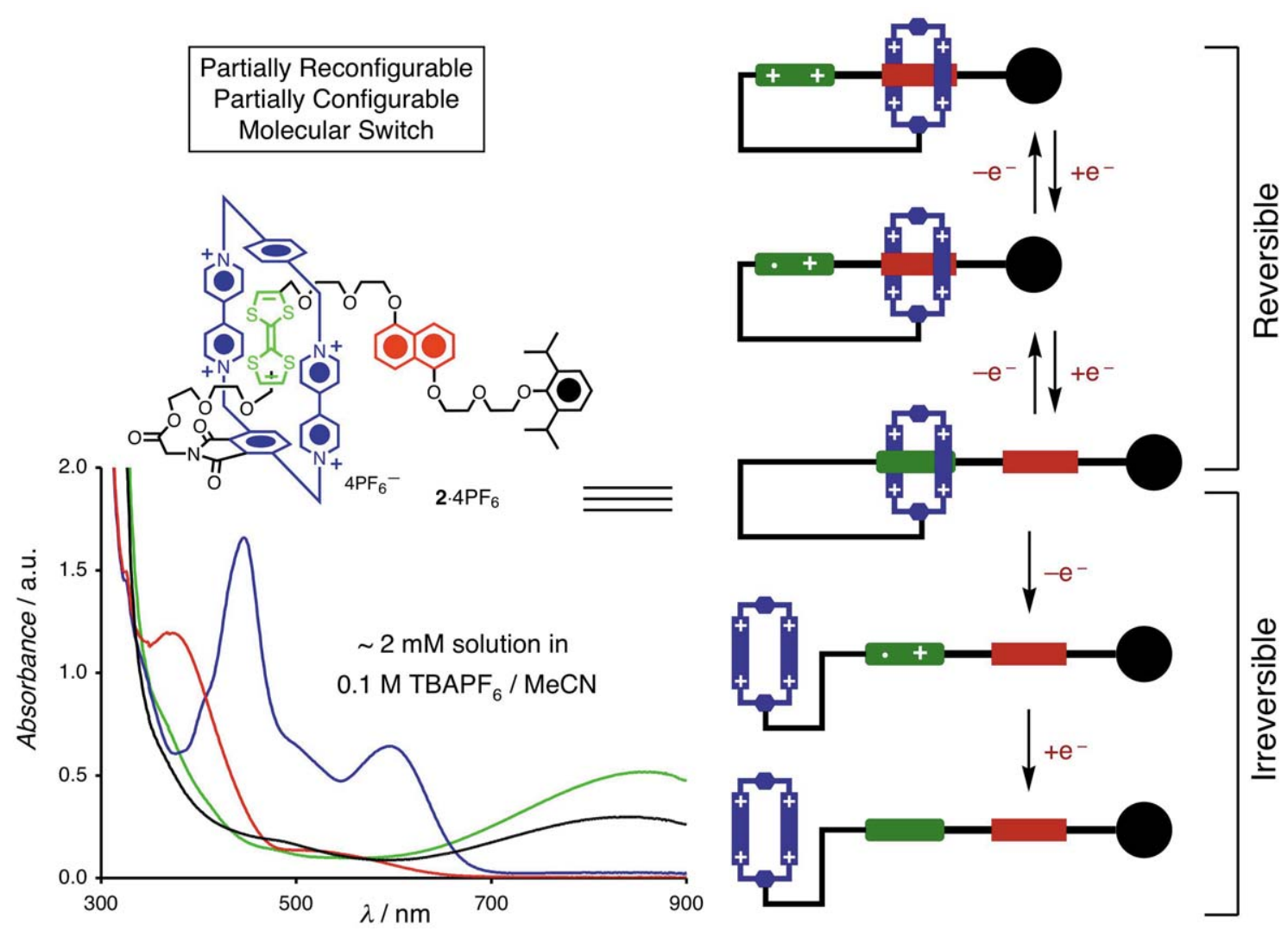

Figure 5 Spectroelectrochemistry and schematic representation illustrating the reversible and irreversible conformational changes involving the TTF/DNP-containing side-arm in $\mathbf{2} \cdot 4 \mathrm{PF}_{6}$ in response to electrochemical inputs. These reversible and irreversible conformational changes correspond to a partially reconfigurable and partially configurable molecular switch, respectively. See the text for an explanation of the colorcoded spectra. 
point determination. Electrochemical and spectroelectrochemical experiments were carried out at r.t. in Ar-purged $\mathrm{MeCN}$ solutions at specific concentrations of the compounds using a Princeton Applied Research 263A Potentiostat/Galvanostat instrument, interfaced to a PC (EG \& G software). Cyclic voltammetric experiments were performed using a glassy-carbon working electrode $\left(0.018 \mathrm{~cm}^{2}\right.$, Cypress Systems). Its surface was polished routinely with a 0.05 micron alumina/ $\mathrm{H}_{2} \mathrm{O}$ slurry on a felt surface immediately before use. The counter electrode was a Pt wire and the reference electrode was either SCE or $\mathrm{Ag} / \mathrm{AgCl}$. Tetrabutylammonium hexafluorophosphate $\left(\mathrm{TBAPF}_{6}, 0.1 \mathrm{M}\right.$ in $\left.\mathrm{MeCN}\right)$ was used as supporting electrolyte. Cyclic voltammograms were obtained at scan rates ranging from 2 to $1000 \mathrm{mV} \mathrm{s}^{-1}$. For reversible processes, $E_{1 / 2}$ was calculated from an average of the cathodic and anodic cyclic voltammetric peaks. To establish the reversibility of a process, we used the criteria of (i) $60 \mathrm{mV}$ between cathodic and anodic peaks, and (ii) close to unity ratio of the intensities of the cathodic and anodic currents. Spectroelectrochemical experiments were made in a custom-built, optically transparent, thin-layer electrochemical (OTTLE) cell with an optical path of $1 \mathrm{~mm}$, using a Pt grid as working electrode, a Pt wire as counter electrode and a $\mathrm{Ag}$ wire pseudoreference electrode. For spectroelectrochemistry, 1-2 mM solutions of the compounds in $0.1 \mathrm{M} \mathrm{TBAPF}_{6} / \mathrm{MeCN}$ were used. Experimental errors: potential values, $\pm 10 \mathrm{mV}$; absorption maxima, $\pm 2 \mathrm{~nm}$.

\section{Compound 4}

A solution of $\mathrm{TsCl}(920 \mathrm{mg}, 4.48 \mathrm{mmol})$ in $\mathrm{CH}_{2} \mathrm{Cl}_{2}(20 \mathrm{~mL})$ was added dropwise into a mixture of the diol $\mathbf{3}^{9}(2.16 \mathrm{~g}, 4.71 \mathrm{mmol})$, $\mathrm{Et}_{3} \mathrm{~N}(1.4 \mathrm{~mL})$ and DMAP (cat.) in $\mathrm{CH}_{2} \mathrm{Cl}_{2}(80 \mathrm{~mL})$ at $0{ }^{\circ} \mathrm{C}$. The mixture was allowed to stir overnight at r.t. after the addition was complete. The solvent was evaporated and the residue was subjected to column chromatography $\left(\mathrm{SiO}_{2}\right.$ : hexanes-EtOAc, 1:4) to give 4 as a colorless oil $(880 \mathrm{mg}, 41 \%)$.

${ }^{1} \mathrm{H} \mathrm{NMR}\left(600 \mathrm{MHz}, \mathrm{CDCl}_{3}, 298 \mathrm{~K}\right): \delta=7.85(\mathrm{t}, J=9.8 \mathrm{~Hz}, 2 \mathrm{H})$, $7.77(\mathrm{~d}, J=8.5 \mathrm{~Hz}, 2 \mathrm{H}), 7.35-7.32(\mathrm{~m}, 2 \mathrm{H}), 7.28(\mathrm{~d}, J=7.6 \mathrm{~Hz}, 2$ $\mathrm{H}), 6.83(\mathrm{t}, J=6.8 \mathrm{~Hz}, 2 \mathrm{H}), 4.29(\mathrm{t}, J=4.5 \mathrm{~Hz}, 2 \mathrm{H}), 4.25(\mathrm{t}, J=4.5$ $\mathrm{Hz}, 2 \mathrm{H}), 4.13(\mathrm{t}, J=4.5 \mathrm{~Hz}, 2 \mathrm{H}), 3.99(\mathrm{t}, J=4.5 \mathrm{~Hz}, 2 \mathrm{H}), 3.94(\mathrm{t}$, $J=4.5 \mathrm{~Hz}, 2 \mathrm{H}), 3.80(\mathrm{t}, J=4.5 \mathrm{~Hz}, 2 \mathrm{H}), 3.73-3.68(\mathrm{~m}, 8 \mathrm{H}), 3.62$ $3.60(\mathrm{~m}, 4 \mathrm{H})$.

${ }^{13} \mathrm{C}$ NMR $\left(150 \mathrm{MHz}, \mathrm{CDCl}_{3}, 298 \mathrm{~K}\right): \delta=155.2,155.1,145.6$, 133.8, 130.7, 128.8, 127.6, 127.6, 126.0, 126.0, 115.5, 115.4, 106.6, 106.5, 73.3, 71.9, 71.8, 71.7, 71.3, 70.7, 70.7, 70.1, 69.6, 68.7, 68.7, $62.7,22.4$.

\section{Compound 5}

A mixture of the monotosylate 4 (770 $\mathrm{mg}, 1.33 \mathrm{mmol})$, 4-hydroxybenzylaldehyde (194 mg, $1.60 \mathrm{mmol}), \mathrm{K}_{2} \mathrm{CO}_{3}(551 \mathrm{mg}, 3.99 \mathrm{mmol})$, $\mathrm{LiBr}$ (cat.) and 18-crown-6 (cat.) in $\mathrm{MeCN}(40 \mathrm{~mL}$ ) was refluxed for $24 \mathrm{~h}$. The resulting suspension was filtered and the solid was washed with acetone until the filtrate was colorless. The combined organic solution was evaporated and subjected to column chromatography $\left(\mathrm{SiO}_{2}\right.$ : hexanes-EtOAc, 1:5) to give $\mathbf{5}$ as a colorless oil (660 mg, 94\%), which slowly solidified upon storage.

${ }^{1} \mathrm{H}$ NMR $\left(500 \mathrm{MHz}\right.$, acetone- $\left.d_{6}, 298 \mathrm{~K}\right): \delta=9.86(\mathrm{~s}, 1 \mathrm{H}), 7.83-$ $7.80(\mathrm{~m}, 4 \mathrm{H}), 7.34(\mathrm{q}, J=7.8 \mathrm{~Hz}, 2 \mathrm{H}), 7.05(\mathrm{~d}, J=7.8 \mathrm{~Hz}, 2 \mathrm{H})$, $6.94(\mathrm{~d}, J=7.6 \mathrm{~Hz}, 2 \mathrm{H}), 4.30(\mathrm{t}, J=4.5 \mathrm{~Hz}, 4 \mathrm{H}), 4.19$ (t, $J=4.5$ $\mathrm{Hz}, 2 \mathrm{H}), 3.96-3.94(\mathrm{~m}, 4 \mathrm{H}), 3.85$ (t, $J=4.5 \mathrm{~Hz}, 2 \mathrm{H}), 3.75-3.68$ $(\mathrm{m}, 6 \mathrm{H}), 3.63-3.50(\mathrm{~m}, 6 \mathrm{H})$.

${ }^{13} \mathrm{C}$ NMR (125 MHz, acetone- $\left.d_{6}, 298 \mathrm{~K}\right): \delta=190.1,163.8,154.4$, 131.4, 130.1, 126.6, 125.0, 114.7, 114.1, 114.1, 105.6, 105.5, 72.6, 70.6, 70.6, 70.5, 70.2, 69.4, 69.4, 69.1, 67.8, 67.8, 61.0. 60.9.

MS (FAB): $m / z(\%)=529.31(75)[\mathrm{M}+\mathrm{H}]^{+}$.

HRMS (MALDI): $m / z$ calcd for $\mathrm{C}_{29} \mathrm{H}_{36} \mathrm{O}_{9} \mathrm{Na}^{+}[\mathrm{M}+\mathrm{Na}]^{+}: 551.2218$; found: 551.2252.

\section{Compound 7}

A mixture of the alcohol 5 (300 mg, $0.57 \mathrm{mmol})$, the carboxylic acid derivative $\mathbf{6}^{8 \mathrm{~b}}$ (244 mg, $\left.0.62 \mathrm{mmol}\right)$, 1,3-dicyclohexylcarbodiimide (233 mg, $1.14 \mathrm{mmol}$ ) and 4-dimethylaminopyridine (cat.) in $\mathrm{CH}_{2} \mathrm{Cl}_{2}$ $(15 \mathrm{~mL})$ was stirred overnight at r.t.. The resulting suspension was filtered and the filtrate was evaporated and subjected to column chromatography $\left(\mathrm{SiO}_{2}\right.$ : hexanes-EtOAc, 1:1) to give the dibromide 7 as a white wax $(0.389 \mathrm{~g}, 76 \%)$.

${ }^{1} \mathrm{H}$ NMR (500 MHz, $\left.\mathrm{CDCl}_{3}, 298 \mathrm{~K}\right): \delta=9.91(\mathrm{~s}, 1 \mathrm{H}), 7.88(\mathrm{t}$, $J=9.0 \mathrm{~Hz}, 2 \mathrm{H}), 7.79(\mathrm{~d}, J=8.7 \mathrm{~Hz}, 2 \mathrm{H}), 7.66(\mathrm{~s}, 2 \mathrm{H}), 7.35(\mathrm{q}$, $J=8.7 \mathrm{~Hz}, 2 \mathrm{H}), 6.97(\mathrm{~d}, J=8.7 \mathrm{~Hz}, 2 \mathrm{H}), 6.85(\mathrm{~d}, J=7.6 \mathrm{~Hz}, 1 \mathrm{H})$, $6.82(\mathrm{~d}, J=7.6 \mathrm{~Hz}, 1 \mathrm{H}), 4.92(\mathrm{~s}, 4 \mathrm{H}), 4.36(\mathrm{t}, J=4.5 \mathrm{~Hz}, 4 \mathrm{H}), 4.32$ (t, $J=4.5 \mathrm{~Hz}, 2 \mathrm{H}), 4.29$ (t, $J=4.5 \mathrm{~Hz}, 2 \mathrm{H}), 4.18(\mathrm{t}, J=4.5 \mathrm{~Hz}, 2$ $\mathrm{H}), 4.04-4.00(\mathrm{~m}, 4 \mathrm{H}), 3.92(\mathrm{t}, J=4.5 \mathrm{~Hz}, 2 \mathrm{H}), 3.86-3.79(\mathrm{~m}, 6$ $\mathrm{H}), 3.76(\mathrm{t}, J=4.5 \mathrm{~Hz}, 2 \mathrm{H}), 3.72(\mathrm{t}, J=4.5 \mathrm{~Hz}, 2 \mathrm{H})$.

${ }^{13} \mathrm{C}$ NMR (125 MHz, acetone- $\left.d_{6}, 298 \mathrm{~K}\right): \delta=190.7,167.0,166.3$, 163.7, 154.2, 154.1, 137.0, 137.4, 131.8, 129.9, 128.2, 126.6, 126.5, $125.0,125.0,114.7,114.5,114.4,105.5,105.5,70.9,70.8,70.8$, 70.7, 69.7, 69.4, 68.7, 67.8, 67.7, 67.6, 64.9, 38.7, 25.7.

HRMS (MALDI): $m / z$ calcd for $\mathrm{C}_{41} \mathrm{H}_{43} \mathrm{Br}_{2} \mathrm{NO}_{12} \mathrm{Na}^{+}[\mathrm{M}+\mathrm{Na}]^{+}$: 922.1022; found: 922.1044 .

\section{Compound 8.2PF}

A solution of dibromide 7 (520 mg, $0.58 \mathrm{mmol}$ ) and 4,4'-bipyridine $(540 \mathrm{mg}, 3.46 \mathrm{mmol})$ in $\mathrm{MeCN}(10 \mathrm{~mL})$ was refluxed for $5 \mathrm{~h}$. The resulting suspension was evaporated to dryness, followed by the addition of sat. aq $\mathrm{NH}_{4} \mathrm{PF}_{6}$ solution. The solid precipitate was collected by filtration. The excess of 4,4'-bipyridine was removed by washing with $\mathrm{Et}_{2} \mathrm{O}$ to give $\mathbf{8} \cdot 2 \mathrm{PF}_{6}$ as a yellow solid (630 mg, 81\%), which was used directly for the next step of the synthesis.

HRMS (ESI): $m / z$ calcd for $\mathrm{C}_{61} \mathrm{H}_{59} \mathrm{~F}_{12} \mathrm{~N}_{5} \mathrm{O}_{12} \mathrm{P}_{2}$ [M $\left.-\mathrm{PF}_{6}\right]^{+}$: 1198.3797; found: 1198.3843 .

\section{Compound 1.4PF}

A solution of the dicationic salt $8 \cdot 2 \mathrm{PF}_{6}(113 \mathrm{mg}, 85.0 \mu \mathrm{mol})$ and the dibromide $\mathbf{9}^{8 \mathrm{~b}}(78 \mathrm{mg}, 85.0 \mu \mathrm{mol})$ in DMF $(3 \mathrm{~mL})$ was stirred at r.t. for $10 \mathrm{~d} . \mathrm{Et}_{2} \mathrm{O}(100 \mathrm{~mL})$ was added to the green reaction mixture to ensure the full precipitation of the reaction product. The green precipitate was filtered off under reduced pressure and subjected to column chromatography $\left(\mathrm{SiO}_{2}: \mathrm{MeOH}-\mathrm{NH}_{4} \mathrm{Cl}(2 \mathrm{M})-\mathrm{MeNO}_{2}\right.$ 7:2:1). The green fractions containing the product were combined and concentrated. $\mathrm{NH}_{4} \mathrm{PF}_{6}$ was added to precipitate the product as a solid, which was further purified by preparative TLC using $\mathrm{MeOH}-$ $\mathrm{NH}_{4} \mathrm{Cl}(2 \mathrm{M})-\mathrm{MeNO}_{2}$ (7:2:1) as the eluent. The band containing the product was washed off the silica gel by using a solution of $\mathrm{NH}_{4} \mathrm{PF}_{6}$ in acetone. The solvent was evaporated off and the residue was washed with $\mathrm{H}_{2} \mathrm{O}$ and $\mathrm{Et}_{2} \mathrm{O}$ separately to give pure $1 \cdot 4 \mathrm{PF}_{6}$ as a green solid (39 mg, 19\%).

${ }^{1} \mathrm{H}$ NMR $\left(500 \mathrm{MHz}\right.$, acetone- $\left.d_{6}, 323 \mathrm{~K}\right): \delta=9.83(\mathrm{~m}, 2 \mathrm{H}), 9.58-$ $9.10(\mathrm{~m}, 8 \mathrm{H}), 8.58-8.16(\mathrm{~m}, 12 \mathrm{H}), 7.85-7.70(\mathrm{~m}, 8 \mathrm{H}), 7.30(\mathrm{~m}, 2$ $\mathrm{H}), 7.10-6.95(\mathrm{~m}, 8 \mathrm{H}), 6.48-6.40(\mathrm{~m}, 6 \mathrm{H}), 4.70-3.65(\mathrm{~m}, 48 \mathrm{H})$.

HRMS (ESI): $m / z$ calcd for $\mathrm{C}_{96} \mathrm{H}_{94} \mathrm{~F}_{24} \mathrm{~N}_{6} \mathrm{O}_{22} \mathrm{P}_{4} \mathrm{~S}_{4}\left[\mathrm{M}-2 \mathrm{PF}_{6}\right]^{2+}$ : 1050.2288; found: $1050.2261 ; \mathrm{m} / \mathrm{z}$ calcd for $\left[\mathrm{M}-3 \mathrm{PF}_{6}\right]^{3+}$ : 651.8310; found: 651.8295 .

\section{Compound 12}

A mixture of $\mathbf{1 0}^{2 \mathrm{e}, \mathrm{f}}(170 \mathrm{mg}, 0.42 \mathrm{mmol})$, the monotosylate $\mathbf{1 1}^{\mathrm{sb}}$ (225 mg, $0.38 \mathrm{mmol}), \mathrm{K}_{2} \mathrm{CO}_{3}(105 \mathrm{mg}, 0.76 \mathrm{mmol})$ and 18-crown$6(5 \mathrm{mg}$, cat.) in anhyd MeCN $(20 \mathrm{~mL})$ was refluxed for $16 \mathrm{~h}$. The mixture was filtered and the solid was washed with $\mathrm{CH}_{2} \mathrm{Cl}_{2}$. The combined organic extracts were concentrated and the residue was purified by column chromatography $\left(\mathrm{SiO}_{2}: \mathrm{CH}_{2} \mathrm{Cl}_{2}-\mathrm{MeOH}, 100: 1\right)$ to give 12 as a yellow semi-solid (231 $\mathrm{mg}, 74 \%)$.

${ }^{1} \mathrm{H}$ NMR (500 MHz, acetone- $\left.d_{6}, 298 \mathrm{~K}\right): \delta=7.94(\mathrm{~d}, J=8.5 \mathrm{~Hz}, 1$ H), $7.91(\mathrm{~d}, J=8.5 \mathrm{~Hz}, 1 \mathrm{H}), 7.48-7.39(\mathrm{~m}, 2 \mathrm{H}), 7.17-7.01(\mathrm{~m}, 3$ 
H), $6.98(\mathrm{~d}, J=8.5 \mathrm{~Hz}, 1 \mathrm{H}), 6.86(\mathrm{~d}, J=8.5 \mathrm{~Hz}, 1 \mathrm{H}), 6.55-6.44$ $(\mathrm{m}, 2 \mathrm{H}), 4.39(\mathrm{~d}, J=4.5 \mathrm{~Hz}, 2 \mathrm{H}), 4.34-4.31(\mathrm{~m}, 6 \mathrm{H}), 4.10(\mathrm{~d}$, $J=4.5 \mathrm{~Hz}, 2 \mathrm{H}), 3.99-3.97(\mathrm{~m}, 6 \mathrm{H}), 3.77(\mathrm{~d}, J=4.5 \mathrm{~Hz}, 2 \mathrm{H})$, $3.66-3.19(\mathrm{~m}, 12 \mathrm{H}), 2.96(\mathrm{~s}, 1 \mathrm{H}), 1.26(\mathrm{~d}, J=8.5 \mathrm{~Hz}, 12 \mathrm{H})$.

${ }^{13} \mathrm{C}$ NMR (125 MHz, acetone- $\left.d_{6}, 298 \mathrm{~K}\right): \delta=154.4,154.3,141.6$, 134.8, 134.7, 134.7, 134.6, 126.7, 125.2, 125.1, 124.5, 123.8, 116.6, $116.5,116.4,114.3,114.2,109.9,109.9,109.8,109.8,105.7,74.1$, 72.6, 70.5, 70.1, 69.7, 69.4, 69.2, 69.2, 69.1, 68.1, 67.9, 67.6, 67.6, 67.6, 61.0, 25.9, 23.5 .

HRMS (MALDI): $\mathrm{m} / \mathrm{z}$ calcd for $\mathrm{C}_{42} \mathrm{H}_{54} \mathrm{O}_{9} \mathrm{~S}_{4}[\mathrm{M}]^{+}: 830.2636$; found: $830.2645 ; \mathrm{m} / \mathrm{z}$ calcd for $[\mathrm{M}+\mathrm{Na}]^{+}:$853.2556; found: 853.2543.

\section{Compound 13}

A mixture of the alcohol 12 (174 mg, $0.21 \mathrm{mmol})$, the carboxylic acid derivative $\mathbf{6}(90 \mathrm{mg}, 0.23 \mathrm{mmol})$, 1,3-dicyclohexylcarbodiimide (86 mg, $0.42 \mathrm{mmol}$ ) and 4-dimethylaminopyridine (cat.) in $\mathrm{CH}_{2} \mathrm{Cl}_{2}(5 \mathrm{~mL})$ was stirred overnight at r.t. The resulting suspension was filtered and the filtrate was evaporated and subjected to column chromatography $\left(\mathrm{SiO}_{2}\right.$ : hexanes-EtOAc, 1:2) to give the dibromide 13 as a brownish-yellow solid (150 mg, 60\%).

${ }^{1} \mathrm{H}$ NMR $\left(500 \mathrm{MHz}\right.$, acetone- $\left.d_{6}, 298 \mathrm{~K}\right): \delta=7.70(\mathrm{~s}, 4 \mathrm{H}), 7.38(\mathrm{~d}$, $J=11 \mathrm{~Hz}, 2 \mathrm{H}), 7.08-7.12(\mathrm{~m}, 3 \mathrm{H}), 6.98-7.02$ (m, $2 \mathrm{H}), 6.28-6.57$ $(\mathrm{m}, 2 \mathrm{H}), 5.07(\mathrm{~s}, 4 \mathrm{H}), 4.50(\mathrm{~s}, 4 \mathrm{H}), 4.36(\mathrm{~d}, J=15 \mathrm{~Hz}, 8 \mathrm{H}), 4.11$ (s, $2 \mathrm{H}), 4.00(\mathrm{~s}, 6 \mathrm{H}), 3.61-3.79(\mathrm{~m}, 10 \mathrm{H}), 3.49-3.51(\mathrm{~m}, 2 \mathrm{H}), 1.20$ $(\mathrm{d}, J=6 \mathrm{~Hz}, 12 \mathrm{H})$.

${ }^{13} \mathrm{C}$ NMR (500 MHz, acetone- $\left.d_{6}, 298 \mathrm{~K}\right): \delta=167.1,166.2,154.4$, 154.3, 153.1, 141.6, 137.2 136.6, 128.3, 126.6, 125.1, 125.0, 124.4, $123.7,116.5,114.2,114.1,105.6,74.0,70.5,70.2,69.7,69.4,69.2$ 69.0, 68.5, 67.8, 64.7, 38.5, 31.3, 25.9, 22.3.

HRMS (MALDI): $\mathrm{m} / z$ calcd for $\mathrm{C}_{54} \mathrm{H}_{61} \mathrm{Br}_{2} \mathrm{NO}_{12} \mathrm{~S}_{4}[\mathrm{M}]^{+}:$: 201.1443 ; found: 1203.1473 .

\section{Compound 2.4PF}

A solution of the dibromide $13(149 \mathrm{mg}, 0.124 \mathrm{mmol})$ and the dicationic salt $14 \cdot 2 \mathrm{PF}_{6}{ }^{10}(87.0 \mathrm{mg}, 0.124 \mathrm{mmol})$ in DMF $(3 \mathrm{~mL})$ was stirred at r.t. for $12 \mathrm{~d}$. The solvent was removed under reduced pressure and the residue was subjected to column chromatography $\left[\mathrm{SiO}_{2}: \mathrm{MeOH}-\mathrm{NH}_{4} \mathrm{Cl}(2 \mathrm{M})-\mathrm{MeNO}_{2}, 7: 2: 1\right]$. The green fractions containing the product were combined and concentrated. $\mathrm{NH}_{4} \mathrm{PF}_{6}$ was added to precipitate the product $2 \cdot 4 \mathrm{PF}_{6}$ as a green solid $(53 \mathrm{mg}$, $21 \%)$.

${ }^{1} \mathrm{H}$ NMR (500 MHz, $\left.\mathrm{CD}_{3} \mathrm{CN}, 348 \mathrm{~K}\right): \delta=8.92-8.90(\mathrm{~m}, 8 \mathrm{H}), 7.00$ $5.98(\mathrm{~m}, 27 \mathrm{H}), 5.73-5.60(\mathrm{~m}, 6 \mathrm{H}), 4.60(\mathrm{~s}, 2 \mathrm{H}), 4.52(\mathrm{~m}, 2 \mathrm{H}), 4.42$ (m, $2 \mathrm{H}), 4.30(\mathrm{~m}, 2 \mathrm{H}), 4.20(\mathrm{~m}, 6 \mathrm{H}), 4.18(\mathrm{~m}, 4 \mathrm{H}), 3.97(\mathrm{~m}, 6 \mathrm{H})$, $3.75(\mathrm{~m}, 4 \mathrm{H}), 3.68(\mathrm{~m}, 2 \mathrm{H}), 3.42(\mathrm{~m}, 2 \mathrm{H}), 1.19(\mathrm{~m}, 12 \mathrm{H})$.

HRMS (ESI): $m / z$ calcd for $\mathrm{C}_{82} \mathrm{H}_{85} \mathrm{~F}_{24} \mathrm{~N}_{5} \mathrm{O}_{12} \mathrm{P}_{4} \mathrm{~S}_{4}\left[\mathrm{M}-2 \mathrm{PF}_{6}\right]^{2+}$ : 874.7175; found: 874.7162 .

\section{Ackowledgment}

This research was supported by the Defense Advanced Research Projects Agency (DARPA) and the Institute of Cell Mimetic Space Exploration (CMISE). Part of this work is based upon research supported by the National Science Foundation (NSF) under equipment grant number CHE-9974928 and CHE-0092036.

\section{References}

(1) (a) Schill, G. Catenenes, Rotaxanes, and Knots; Academic Press: New York, 1971. (b) Molecular Catenanes, Rotaxanes, and Knots; Sauvage, J.-P.; Dietrich-Buchecker, C. O., Eds.; Wiley-VCH: Weinheim, 1999.
(2) (a) Bissell, R. A.; Córdova, E.; Kaifer, A. E.; Stoddart, J. F. Nature 1994, 369, 133. (b) Anelli, P.-L.; Asakawa, M.; Ashton, P. R.; Bissell, R. A.; Clavier, G.; Górski, R.; Kaifer, A. E.; Langford, S. J.; Mattersteig, G.; Menzer, S.; Philp, D.; Slawin, A. M. Z.; Spencer, N.; Stoddart, J. F.; Tolley, M. S.; Williams, D. J. Chem. Eur. J. 1997, 3, 1136. (c) Jeppesen, J. O.; Nielsen, K. A.; Perkins, J.; Vignon, S. A.; Di Fabio, A.; Ballardini, R.; Gandolfi, M. T.; Venturi, M.; Balzani, V.; Becher, J.; Stoddart, J. F. Chem. Eur. J. 2003, 9, 2982. (d) Jeppesen, J. O.; Vignon, S. A.; Stoddart, J. F. Chem. Eur. J. 2003, 9, 4611. (e) Tseng, H.-R.; Vignon, S. A.; Stoddart, J. F. Angew. Chem. Int. Ed. 2003, 42, 1491. (f) Tseng, H.R.; Vignon, S. A.; Celestre, P. C.; Perkins, J.; Jeppesen, J. O.; Di Fabio, A.; Ballardini, R.; Gandolfi, M. T.; Venturi, M.; Balzani, V.; Stoddart, J. F. Chem. Eur. J. 2004, 10, 155. (g) Laursen, B. W.; Nygaard, S.; Jeppesen, J. O.; Stoddart, J. F. Org. Lett. 2004, 6, 4167. (h) Iijima, T.; Vignon, S. A.; Tseng, H.-R.; Jarrosson, T.; Sanders, J. K. M.; Marchioni, F.; Venturi, M.; Apostoli, E.; Balzani, V.; Stoddart, J. F. Chem. Eur. J. 2004, 10, 6375. (i) Jeppesen, J. O.; Nygaard, S.; Vignon, S. A.; Stoddart, J. F. Eur. J. Org. Chem. 2005, 196.

(3) (a) Stoddart, J. F. Chem. Aust. 1992, 59, 576. (b) Stoddart, J. F. Chem. Aust. 1992, 59, 581. (c) Gómez-López, M.; Preece, J. A.; Stoddart, J. F. Nanotechnology 1996, 7, 183. (d) Balzani, V.; Gómez-López, M.; Stoddart, J. F. Acc. Chem. Res. 1998, 31, 405. (e) Balzani, V.; Credi, A.; Raymo, F. M.; Stoddart, J. F. Angew. Chem. Int. Ed. 2000, 39, 3348. (f) Harada, A. Acc. Chem. Res. 2001, 34, 456. (g) Schalley, C. A.; Beizai, K.; Vögtle, F. Acc. Chem. Res. 2001, 34, 465. (h) Collin, J.-P.; Dietrich-Buchecker, C.; Gaviña, P.; Jiménez-Molero, M. C.; Sauvage, J.-P. Acc. Chem. Res. 2001, 34, 477. (i) Ballardini, R.; Balzani, V.; Credi, A.; Gandolfi, M. T.; Venturi, M. Struct. Bonding (Berlin) 2001, 99, 163. (j) Raehm, L.; Sauvage, J.-P. Struct. Bonding (Berlin) 2001, 99, 55. (k) Stainer, C. A.; Alderman, S. J.; Claridge, T. D. W.; Anderson, H. L. Angew. Chem. Int. Ed. 2002, 41, 1769. (1) Balzani, V.; Credi, A.; Venturi, M. Chem. Eur. J. 2002, 8, 5524. (m) Tseng, H.-R.; Stoddart, J. F. Modern Arene Chemistry; Astruc, D., Ed.; Wiley-VCH: Weinheim, 2002, 574-599. (n) Balzani, V.; Credi, A.; Venturi, M. Molecular Devices and Machines - A Journey into the Nano World; Wiley-VCH: Weinheim, 2003. (o) Flood, A. H.; Ramirez, R. J. A.; Deng, W.-Q.; Muller, R. P.; Goddard, W. A. III; Stoddart, J. F. Aust. J. Chem. 2004, 57, 301.

(4) (a) Kelly, T. R.; Silva, H. D.; Silva, R. A. Nature 1999, 401, 150. (b) Koumura, N.; Zijlstra, R. W.; van Delden, R. A.; Harada, H.; Feringa, B. L. Nature 1999, 401, 152. (c) Yokoyama, Y. Chem. Rev. 2000, 100, 1717. (d) Berkovic, G.; Krongauz, V.; Weiss, V. Chem. Rev. 2000, 100, 1741. (e) Feringa, B. L.; van Delden, R. A.; Koumura, N.; Geertsema, E. M. Chem. Rev. 2000, 100, 1789. (f) Kelly, T. R. Acc. Chem. Res. 2001, 34, 514. (g) Shinkai, S.; Ikeda, M.; Sugasaki, A.; Takeuchi, M. Acc. Chem. Res. 2001, 34, 494. (h) Oh, K.; Jeong, K.-S.; Moore, J. S. Nature 2001, 414, 889. (i) Koumura, N.; Geertsema, E. M.; van Gelder, M. B.; Meetsma, A.; Feringa, B. L. J. Am. Chem. Soc. 2002, 124, 5037. (j) Hawthorne, F.; Zink, J. I.; Skelton, J. M.; Bayer, M. J.; Liu, C.; Livshits, E.; Baer, R.;

Neuhauser, D. Science 2004, 303, 1849. (k) de Jong, J. J. D.; Lucas, L. N.; Kellogg, R. M.; van Esch, J. H.; Feringa, B. L. Science 2004, 304, 278.

(5) (a) Lane, A. S.; Leigh, D. A.; Murphy, A. J. Am. Chem. Soc. 1997, 119, 11092. (b) Ashton, P. R.; Ballardini, R.; Balzani, V.; Baxter, I.; Credi, A.; Fyfe, M. C. T.; Gandolfi, M. T.; Gómez-López, M.; Martínez-Díaz, M.-V.; Piersanti, A.; 
Spencer, N.; Stoddart, J. F.; Venturi, M.; White, A. J. P.; Williams, D. J. J. Am. Chem. Soc. 1998, 120, 11932. (c) Lee, J. W.; Kim, K.; Kim, K. Chem. Commun. 2001, 1042. (d) Elizarov, A. M.; Chiu, H.-S.; Stoddart, J. F. J. Org. Chem. 2002, 67, 9175. (e) Kaiser, G.; Jarrosson, T.; Otto, S.; Ng, Y.-F.; Bond, A. D.; Sanders, J. K. M. Angew. Chem. Int. Ed. 2004, 43, 1959. (f) Liu, Y.; Flood, A. H.; Stoddart, J. F. J. Am. Chem. Soc. 2004, 126, 9150. (g) Vignon, S. A.; Jarrosson, T.; Iijima, T.; Tseng, H.-R.; Sanders, J. K. M.; Stoddart, J. F. J. Am. Chem. Soc. 2004, 126, 9884.

(6) (a) Raehm, L.; Kern, J. M.; Sauvage, J.-P. Chem. Eur. J. 1999, 5, 3310. (b) Bermudez, V.; Capron, N.; Gase, T.; Gatti, F. G.; Kajzar, F.; Leigh, D. A.; Zerbetto, F.; Zhang, S. Nature 2000, 406, 608. (c) Kern, J.-M.; Raehm, L.; Sauvage, J.-P.; Divisia-Blohorn, B.; Vida, P.-L. Inorg. Chem. 2000, 39, 1555. (d) Ballardini, R.; Balzani, V.; Dehaen, W.; Dell'Erba, A. E.; Raymo, F. M.; Stoddart, J. F.; Venturi, M. Eur. J. Org. Chem. 2000, 591. (e) Balzani, V.; Credi, A.; Mattersteig, G.; Matthews, O. A.; Raymo, F. M.; Stoddart, J. F.; Venturi, M.; White, A. J. P.; Williams, D. J. J. Org. Chem. 2000, 65, 1924. (f) Collin, J.-P.; Kern, J.-M.; Raehm, L.; Sauvage, J.-P. Molecular Switches; Feringa, B. L., Ed.; Wiley-VCH: Weinheim, 2000, 249-280. (g) Altieri, A.; Gatti, F. G.; Kay, E. R.; Leigh, D. A.; Paolucci, F.; Slawin, A. M. Z.; Wong, J. K. Y. J. Am. Chem. Soc. 2003, 125, 8644. (h) Poleschak, I.; Kern, J.-M.; Sauvage, J.-P. Chem. Commun. 2004, 474.

(7) (a) Ballardini, R.; Balzani, V.; Gandolfi, M. T.; Prodi, L.; Venturi, M.; Philp, D.; Ricketts, H. G.; Stoddart, J. F. Angew. Chem., Int. Ed. Engl. 1993, 32, 1301. (b) Ashton, P. R.; Ballardini, R.; Balzani, V.; Credi, A.; Dress, R.; Ishow,
E.; Kocian, O.; Preece, J. A.; Spencer, N.; Stoddart, J. F.; Venturi, M.; Wenger, S. Chem. Eur. J. 2000, 6, 3558. (c) Brower, A. M.; Frochot, C.; Gatti, F. G.; Leigh, D. A.; Mottier, L.; Paolucci, F.; Roffia, S.; Wurpel, G. W. H. Science 2001, 291, 2124. (d) Collin, J.-P.; Laemmel, A.-C.; Sauvage, J.-P. New J. Chem. 2001, 25, 22. (e) Bottari, G.; Leigh, D. A.; Pérez, E. M. J. Am. Chem. Soc. 2003, 125, 1360. (f) Gatti, F. G.; Len, S.; Wong, J. K. Y.; Bottari, G.; Altieri, A.; Morales, M. A. F.; Teat, S. J.; Frochot, C.; Leigh, D. A.; Brower, A. M.; Zerbetto, F. Proc. Natl. Acad. Sci. U.S.A. 2003, 100, 10. (g) Altieri, A.; Bottari, G.; Dehez, F.; Leigh, D. A.; Wong, J. K. Y.; Zerbetto, F. Angew. Chem. Int. Ed. 2003, 42, 2296. (h) Brower, A. M.; Fazio, S. M.; Frochot, C.; Gatti, F. G.; Leigh, D. A.; Wong, J. K. Y.; Wurpel, G. W. H. Pure Appl. Chem. 2003, 75, 1055.

(i) Pérez, E. M.; Dryden, D. T. F.; Leigh, D. A.; Teobaldi, G.; Zerbetto, F. J. Am. Chem. Soc. 2004, 126, 12210.

(8) (a) Liu, Y.; Flood, A. H.; Stoddart, J. F. J. Am. Chem. Soc. 2004, 126, 9150. (b) Liu, Y.; Flood, A. H.; Moskowitz, R. M.; Stoddart, J. F. Chem. Eur. J. 2005, 11, 369. (c) Liu, Y.; Bonvallet, P. A.; Vignon, S. A.; Khan, S. I.; Stoddart, J. F. Angew. Chem. Int. Ed. 2005, 44, 3050. (d) Liu, Y.; Vignon, S. A.; Zhang, X.; Houk, K. N.; Stoddart, J. F. Chem. Commun. 2005, 3927.

(9) Bravo, J. A.; Raymo, F. M.; Stoddart, J. F.; White, A. J. P.; Williams, D. J. Eur. J. Org. Chem. 1998, 2565.

(10) Ashton, P. R.; Ballardini, R.; Balzani, V.; Boyd, S. E.; Credi, A.; Gandolfi, M. T.; Gómez-López, M.; Iqbal, S.; Philp, D.; Preece, J. A.; Prodi, L.; Ricketts, H. G.; Stoddart, J. F.; Tolley, M. S.; Venturi, M.; White, A. J. P.; Williams, D. J. Chem. Eur. J. 1997, 3, 152.

(11) Perrin, D. D.; Armarego, W. L. F. Purification of Laboratory Chemicals; Pergamon: New York, 1998. 